\title{
Investigating the Economic and Financial Damage around Currency Peg Failures
}

\author{
Colin Ellis ${ }^{1, *}$ and Emilia Gyoerk ${ }^{2}$ \\ 1 Department of Economics, University of Birmingham, Birmingham B15 2TT, UK \\ 2 Formerly Moody's Investors Service, London E14 5FA, UK; emilia.gyork@gmail.com \\ * Correspondence: c.ellis@bham.ac.uk
}

Received: 1 May 2019; Accepted: 22 May 2019; Published: 30 May 2019

\begin{abstract}
The choice and structure of a country's exchange rate regime has wide implications for the effectiveness and flexibility of monetary policy tools, as well as for economic and financial stability. We examine 21 instances where exchange rate pegs have been abandoned in the past, to gauge the potential economic damage associated with pegs failing. The sample includes major exchange rate shifts over the past thirty years, spanning from the Latin America currency crises of the 1990s to the peg abandonment in Egypt in 2016. Given the close interconnection of banks to the sovereign and the real economy, risks often flow through to, and can also be magnified by, the banking system. We therefore examine the interaction of currency peg abandonment with the occurrence of a banking crisis to investigate the different circumstances and impacts of exchange rate pegs failing. We have found that countries that simultaneously suffered a systemic banking crisis during the period of exchange rate regime shift also experienced significantly greater economic and financial damage following the adoption of a freely floating exchange rate. Nevertheless, regardless of whether there was a banking crisis, countries start showing signs of recovery after the same amount of time once the currency floated.
\end{abstract}

Keywords: exchange rates; currency pegs; banking crises

\section{Introduction}

The choice and structure of a country's exchange rate regime has wide implications for the effectiveness and flexibility of policy tools, as well as for economic and financial stability. One option is to peg the domestic currency to a foreign one; but if that peg proves to be unsustainable, the macroeconomic and financial damage when the peg breaks can be substantial. Recently, the dollar pegs of certain Gulf Cooperation Council (GCC) countries came under pressure after the fall in oil prices in 2014-15 exacerbated fiscal and current account deficits, leading to substantial declines in foreign exchange reserves. In particular, the Bahraini and Omani pegs became vulnerable and were exposed to market speculation as a result of weak balance of payments positions, strong reductions in foreign exchange reserves, and rising public debt. Before this, a number of pegged currencies among Commonwealth of Independent States countries also experienced significant pressure in the aftermath of the fall in oil prices and sanctions on Russia.

In some instances, past pressures of maintaining an exchange rate peg have ultimately led countries to abandon them in favour of a floating exchange rate. Such institutional shifts have often been preceded by factors including (1) instabilities in the banking sector stemming from its ties to the real economy and the sovereign; (2) depletion of foreign reserves and a lack of policy tools for the central bank to support the economy; (3) broader economic deterioration leading to defaults; and (4) political turmoil, has led many countries to abandon their exchange rate pegs in favour of a floating exchange rate and regained policy control. Importantly, policy stances and broader macrofinancial 
conditions can often be highly detrimental for the domestic credit environment before the peg is abandoned, such that continued defense of the peg would have caused significantly greater economic and financial damage than the abandonment did.

Whenever exchange rate pegs fail, the macroeconomic and financial fallout associated with the failure can be substantial, with widespread associated negative effects across a range of domestic issuers. In this paper, we examine 21 instances where exchange rate pegs have been abandoned in the past, to gauge the potential economic and financial turmoil associated with pegs failing. The data sample covers a select number of major exchange rate shifts over the past thirty years, spanning from the Latin America currency crises of the 1990s to the recent peg abandonment in Egypt at the end of 2016. Whether the shift from a managed exchange rate regime to floating occurs in conjunction with wider systemic economic and financial stress, or whether it takes place in a more contained fashion, has implications for the magnitude and persistence of the economic and financial turmoil at the time the peg is abandoned. Given the close interconnection of banks to the sovereign and real economies, the build-up of risks often flows through to, and can also be magnified by, the banking system. We therefore examine the interaction of currency peg abandonment with the simultaneous occurrence of a banking crisis to investigate the different circumstances and impacts of exchange rate pegs failing. We find that countries that simultaneously suffered a systemic banking crisis during the period of exchange rate regime shift also experienced significantly greater economic and financial damage following the adoption of a freely floating exchange rate. Nevertheless, in general, the timing of the peak impact of peg failures on growth and other economic variables were broadly similar across countries that saw banking crises, and across those that did not. This suggests that all countries generally began to see some degree of recovery at a similar point in time following peg abandonment.

This paper is organized as follows. The subsequent section provides a motivation for our study and an introduction to the theories surrounding monetary policy design with regards to fixed exchange rate regimes as well as the transmission channels from the exchange rate to the broader economy. The third section outlines the data used, while the fourth section illustrates the results found. The fifth section is our conclusion.

\section{Background}

The choice, structure, and alteration of a country's exchange rate regime has important credit implications, as can any shift in policy regime. One well-known description of the choices facing monetary policymakers is the so-called "impossible trinity", or monetary policy trilemma, coined by Mundell $(1960,1963)$ and Fleming (1962). This states that it is impossible to simultaneously pursue all of the following: a fixed exchange rate, an independent monetary policy (most often to target domestic inflation), and allowing the free flow of capital.

The trilemma can be understood from various viewpoints. As an illustration, suppose a central bank is pursuing a fixed exchange rate policy and there is free movement of capital, but then the central bank independently sets a policy interest rate that is lower than that of the foreign anchor currency issuer (the supplier of the peg currency). There will be an economic incentive to sell the domestic currency, which yields a lower interest rate in favour of the foreign currency that yields more. The domestic currency would thus depreciate in value and fuel domestic inflationary pressures. To keep the value of the domestic currency, the central bank has the following options: (1) buy the surplus domestic currency in exchange for the foreign currency. But this is only viable as long as there are sufficient foreign exchange reserves available, and therefore may not be a long-term solution; (2) the central bank has to mirror the interest rate of the foreign country to reduce depreciation pressures. This will cause the central bank to lose monetary policy independence, as it cannot freely set its policy interest rate while maintaining the exchange rate peg; or (3) the central bank needs to limit the flow of capital to maintain the domestic currency value and its chosen interest rate. The country and its citizens, therefore, might not gain from the benefits of free transfer of funds. 
In practice, two out of these three features are achievable. Importantly, however, the trilemma still implies that the domestic central bank needs to pay close attention to external developments: whatever the choice of policy goals and instruments, the implementation of policy will not be immune to global developments.

Recent academic literature (e.g., Rey 2015) has argued that, given the emergence of a global financial cycle, the trilemma effectively transforms into a dilemma in which the central bank is faced with an irreconcilable arrangement where independent monetary policy is possible if and only if the capital account is managed, regardless of the exchange rate regime. In one sense, this is akin to global factors having a greater (or even dominant) role in the determination of the optimal domestic monetary stance. However, this dilemma perspective does not obviate the fact that domestic monetary policy can only focus on a single nominal anchor-either an inflation target, or a fixed exchange rate (essentially, an exchange rate target) - despite the fact that the suitable policy choices for either will depend at least in part on external developments.

Other authors have also investigated the fallout from currency regime changes, and the interaction with the banking sector. One notable contribution is from Hutchinson and Noy (2005), who examine the output costs of currency and banking crises, using an emerging market data sample ending in 1997. They find that both currency and banking crises have separate negative effects on output, yet also find that there is little sign of a multiplicative effect-extra output losses from banking and currency crises occurring simultaneously. This contrasts somewhat with Aghion et al. (2001), who consider how a banking crisis may be exacerbated if a currency crisis occurs at the same time, where a sharp devaluation can push near-insolvent banks into bankruptcy. It is noteworthy that the modelling approach used by Hutchinson and Noy (2005) fails to capture most of the variation evident in emerging market output growth, and we have seen a number of currency crises in recent years that have exhibited different characteristics.

Another notable contribution is from Chang and Velasco (2000), who posit that the nature of the exchange rate regime may influence the likelihood of each type of crisis (banking and currency), brought by self-fulfilling runs. They find that international illiquidity is fundamental in the joint occurrence of banking and currency crises, reflecting either common factors or spillover effects. In a similar vein, Kaminsky and Reinhart (1999) find common causes in the incidence of so-called twin crises (banking and currency), but notably do not conclude that a twin crisis will always be larger than the combined effect of the two crises measured independently.

Other research has focused on various aspects related to these studies. For instance, Cavallo et al. (2005) and Gupta et al. (2003) focus on the output cost of currency crises, while Arteta and Eichengreen (2002), among others, focus on output costs of banking crises. Other work has focused on the transmission channels of financial crises to output losses, such as Corsetti et al. (1998) and Dekle and Kletzer (2001).

However, it is notable that much of this work pre-dates the global financial crisis in 2007/8, and hence does not account for the significant financial and economic changes seen since the mid-2000s, or, as noted above, the currency and banking crises seen since that time. As globalisation has spread and capital controls have been seen as relatively less effective or desirable, countries that have opted to peg their exchange rates ${ }^{1}$ have effectively sacrificed autonomy over domestic monetary policy. In other words, allowing for free movement of capital while pursuing a fixed exchange rate means the domestic central bank must apply an interest rate policy that is aligned with that of the country issuing the currency it is pegged to.

As long as economic fluctuations are aligned and both economies can support synchronous movements in the exchange rate, a fixed exchange rate helps add stability and anchors inflation

1 The value of the domestic currency may be pegged against a single foreign anchor currency or against a basket of different foreign currencies. 
expectations. This has been highly beneficial for many emerging market economies and encouraged capital inflows. However, passive adoption of the monetary policy stance of the anchor country is also a key reason why exchange rate pegs can fail. ${ }^{2}$ If economic cycles start to deviate across countries, applying the same monetary policy can be procyclical and exacerbate these fluctuations, exposing the pegging country to an interest rate that is too high or too low given domestic macroeconomic conditions.

As an example, if the US — which has served as the anchor currency issuer for several other countries $^{3}$ - experiences stronger growth and appreciation pressures, it may apply a higher policy interest rate to prevent economic overheating. If at the same time, the pegging country experiences headwinds to growth but maintains its currency peg to the US dollar (USD), it not only adopts a too-high interest rate relative to domestic activity, but also adopts an appreciating exchange rate (relative to other currencies) that reduces the relative competitiveness of that country's products. This combined effect weighs on domestic growth, with the associated negative effects for a range of market participants. The mechanism naturally works in reverse as well, with accommodative US monetary policy fueling economic overheating in pegged countries.

Once a currency peg starts to come under pressure and it is deemed unsustainable to defend the peg, countries choose a range of options in the transition to a floating regime: from abruptly breaking the peg to progressively allowing increasingly large deviations from the stated peg. ${ }^{4}$ These different regime shifts, in turn, further shape not just the exchange rate adjustment itself, but also the macroeconomic consequences. All instances that we consider have originated from periods of increasing instability leading ultimately to pegs being abandoned. Speculation, policy uncertainty and political turmoil often prompt exchange rate liberalisation as a way to restore stability.

The economic impact of a fall in the exchange rate, as is typical following peg abandonment, will depend on its trigger and the wider circumstances of exchange rate regime shift. ${ }^{5}$ A decline in the exchange rate is essentially a re-pricing of the economy, relative to other economies. As such, domestic firms that use foreign inputs will suffer higher costs; this will hit profitability and/or result in higher domestic selling prices. Higher import prices often feed into higher producer and consumer prices over a long period of time, due to elongated supply chains.

However, domestic firms that compete with foreign firms may see positive impacts. The higher price of imports will likely lead to a fall in import volumes, both if customers switch to buying from domestic producers and because of the general fall in spending due to their weaker purchasing power. And a weaker exchange rate is generally positive for exporting firms, boosting either export volumes or margins, depending on whether firms adjust either the foreign or domestic price of exports. The depreciation of sterling between late 2007 and early 2009 shows that effects can be mixed: UK export prices responded first in sterling terms, rising as the depreciation took hold; and while prices initially fell in foreign-currency terms, UK exporters then offset this. By 2011, the foreign-currency price of UK exports was little changed from 2007, while the sterling price was significantly higher (Figure 1).

The ultimate reasons for why certain countries abandon their pegs and others do not vary widely and are often highly idiosyncratic across countries.

3 The US Dollar has also served as the de facto global reserve currency for the past six decades, and is predicted to continue to serve this purpose for the foreseeable future (Ellis and Smartt 2018).

4 For further description of the circumstances around the peg failure, see the Tables A1 and A2 in the Appendix A.

5 The description of transmission channels from the exchange rate to the broader economy draws on work by Ellis et al. (2015). 


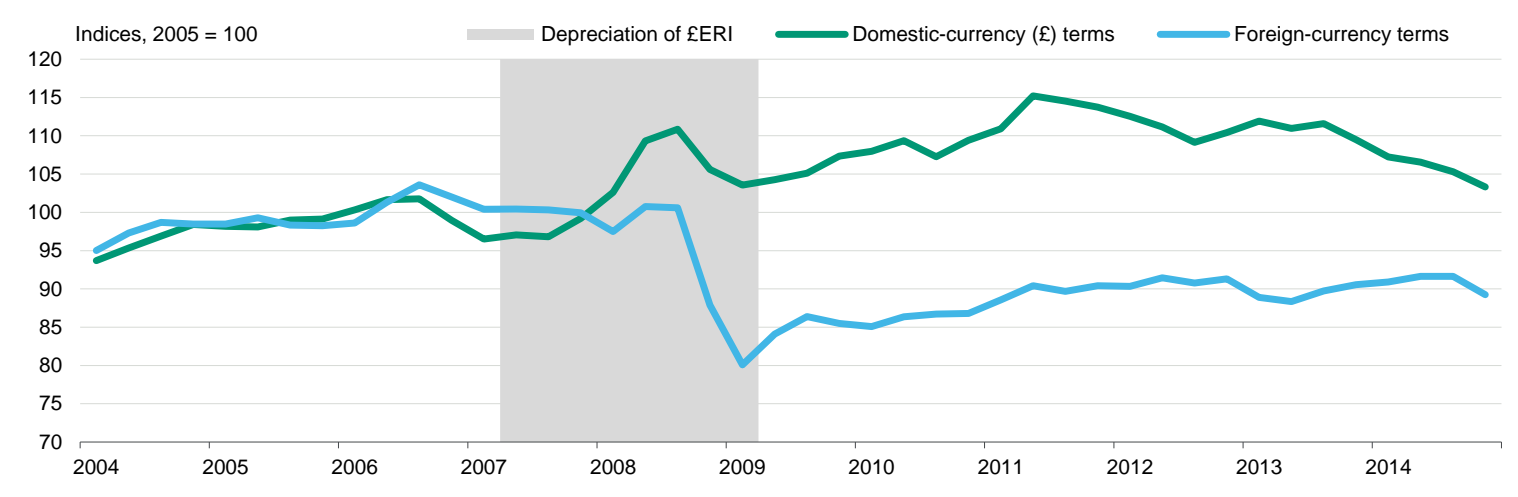

Figure 1. An illustration of diverging foreign- and domestic-currency export prices. The UK goods export prices in sterling terms and in foreign currency terms, around the time of the significant $25 \%$ depreciation in the sterling exchange rate index (ERI) from 2007 until 2009.

Over time, a weaker exchange rate will generally boost export values relative to imports, thereby improving trade and current account balances, although in the short term both can deteriorate if prices respond more swiftly than volumes. As such, countries with large current account deficits are likely to be more vulnerable to a depreciation in their exchange rate. Such a depreciation will help to rebalance external and internal demand in the economy, which also typically provides some short-term boost to GDP growth via weaker imports and/or stronger exports. Correspondingly, a currency appreciation can temporarily weigh on GDP growth via weaker exports and stronger imports.

Trade-dependent entities-both sovereigns and corporates-are most exposed to these effects. Companies focused in commoditised goods such as basic raw materials-for instance, some chemicals or metal products-are particularly exposed to these effects of changes in the relative value of currencies. However, commodity producers whose exports are traded in a common currency (typically the US dollar) are generally insulated from these pricing and volume effects. Instead, currency movements will typically have more impact on margins, if some of these costs are in domestic currency terms.

Exchange rates also affect the household sector. Consumers often spend a significant proportion of their income on imports; and the higher prices of these goods and services, following the exchange rate decline, implies a fall in the real consumption wage-households' earnings relative to consumer prices. This often manifests as a short-term rise in consumer price inflation.

A currency depreciation can also affect household and corporate balance sheets. The value of foreign assets will increase, in domestic currency terms, which could mitigate any drag from weaker profitability or real wages; however, this may be offset by increases in foreign liabilities. Domestic assets will also be cheaper to foreigners, which could encourage inward investment flows. However, the trigger for the exchange rate movement is important here; if the currency decline reflects higher risk premia, then capital outflows are likely in the short term and may only stabilise over time, weighing on medium-term growth prospects.

Finally, a fall in the exchange rate may also trigger responses from domestic policymakers. Because exchange rates are relative prices, the impact on (measured) inflation will only be temporary if the central bank credibly targets inflation; if medium-term inflation expectations are anchored, central banks can look through the relative price shock. In contrast, if expectations are not anchored, then there is a risk of second-round effects-higher prices could feed into higher wages, which in turn could feed back into higher prices or unemployment. In these scenarios-or if the fall in the exchange rate is accompanied by a sharp increase in capital outflows-the central bank could be forced to raise policy rates, thereby increasing funding costs for banks, companies and households.

We aim to shed light on the different experiences surrounding the abandonment of a peg, to gauge the potential economic and financial turmoil associated with pegs failing. Given the close interconnection of banks to the sovereign and real economies, we further evaluate how the interaction of an exchange rate regime shift with the occurrence of a systemic banking crisis impacts the observed 
outcomes. We further add value by assessing the persistence of the economic and financial costs borne by peg abandonment, and how this is impacted by a banking crisis.

\section{Materials and Methods}

We examine 21 instances where exchange rate pegs have been abandoned in the past, to gauge the potential economic and financial turmoil associated with pegs failing. Importantly, we conduct our analysis using an event study rather than formally adopting quantitative modelling. This partly reflects the wide variation in experience across crises, as reflected in the poor fit of some modeling in past research. Importantly, we do not try to ascribe causality between currency crises and other events such as banking crises; we simply examine deviations in output and other macroeconomic variables following the crisis. In doing so, we hope to establish the broad range of outcomes that other countries may see when future crises occur.

The data sample is described in the appendix, and covers a selected number of major exchange rate shifts over the past thirty years, spanning from the Latin America currency crises during the 1990s to the recent peg abandonment in Egypt at the end of 2016. We are primarily concerned with assessing the impact for the following macroeconomic variables: the exchange rate of the domestic currency to the peg anchor currency (normally the US Dollar), real GDP and its growth rate, inflation, and unemployment. All data are collected from public sources. We apply an event study approach in which we examine the 18 months leading up to, and the 18 months following, the month of peg abandonment to capture and isolate the peak of the impact of currency peg failure. In considering the interaction of currency peg failure with banking crisis, we draw on the definition and database on systemic banking crises developed by Laeven and Valencia (2018). Their definition of a systemic banking crisis fulfils two criteria along the dimensions of severity of crisis and policy responses:

1. There are significant bank runs, losses in the banking system, and/or bank liquidations; and

2. There are significant policy interventions to combat these losses in the banking system.

Figure 2 shows the countries that suffered a systemic banking crisis and when that crisis erupted in relation to the month of the peg breaking. Ten countries, or about half the sample, experienced a banking crisis, and we use this as a means to split our sample in order to investigate the different impacts of exchange rate pegs failing. In most cases where there was a systemic banking crisis, it broke out within a few months after the peg failed, indicating a coincidence of the peak of the pressure on the peg and the systemic banking crisis entering full force.

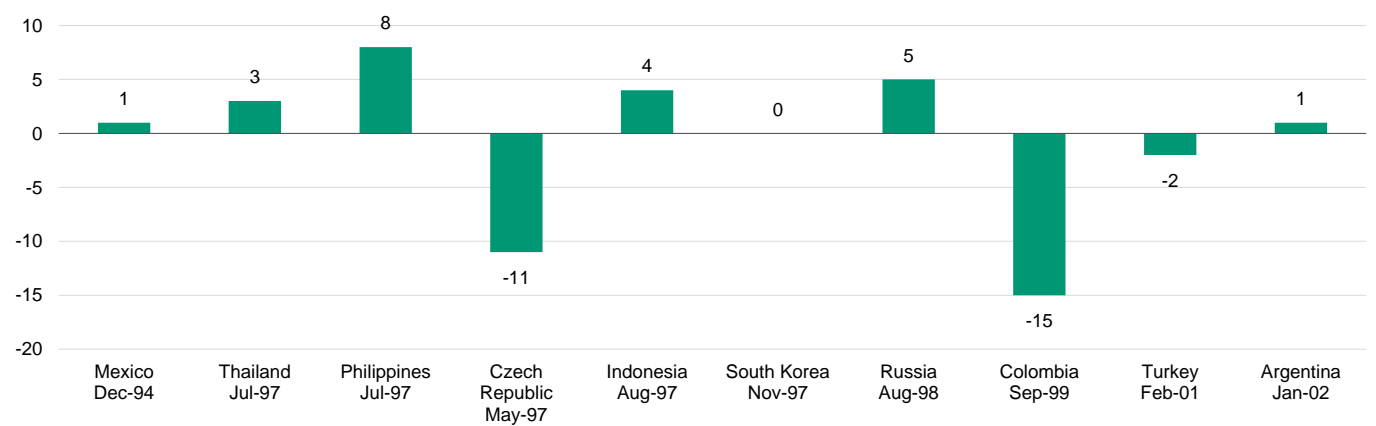

Figure 2. Timing of systemic banking crises in relation to the month of currency peg failure. The figure shows the number of months' difference from the time of the currency peg breaking to the systemic banking crisis erupting, as defined by Laeven and Valencia (2018). A negative number signifies the systemic banking crisis erupted before the peg failed, while a positive number indicates the banking crisis broke out after the adoption of the floating currency. In South Korea, the banking crisis became systemic in the same month as the currency was floated. Although Azerbaijan suffered a crisis in its banking sector when the largest bank, International Bank of Azerbaijan, suspended payments on some of its liabilities in 2017 and restructured $\$ 3.3$ billion of debt, the crisis was not systemic in nature as defined by Laeven and Valencia, and is therefore not featured in the exhibit. 
However, there are also instances where the banking crisis came first. In particular, in both the Czech Republic and Colombia, the banking crises became systemic around a year before the pegs were abandoned. It is likely that the damaging impact of these banking crises provided motivation for the countries' central banks to mitigate pressure on their currencies. Both countries adopted increasingly lax exchange rate arrangements in the year before abandoning their managed regimes altogether. Immediately before the authorities let the pegs fail, the Czech Republic allowed deviations of $\pm 15 \%$ around the stated exchange rate peg, while Colombia allowed fluctuations of $\pm 10 \%$. But it also serves to demonstrate that banking crises do not always follow currency crises, and it is possible for causality to run the other way.

\section{Results}

Although all episodes of exchange rate regime shifts from managed into freely floating have been disruptive in our sample, the macrofinancial damage associated with some cases was more damaging than others. Many factors affect the severity of impact, including risk build-up and contagion across sectors, as well as the adaptability, timeliness and adequacy of policy responses. The currency peg failures in Russia in 1998 and in Argentina in 2002 were both accompanied by sovereign defaults, resulting in particularly severe economic and financial damage. At the other end of the spectrum, Iceland in 2001 and Kazakhstan in 2015 experienced more muted consequences of dropping their exchange rate pegs.

On average, countries that suffered a banking crisis recorded the greatest exchange rate depreciation six months after the peg broke (see Figure 3). The currency had then lost almost half its value compared to its level in the month the peg was abandoned. In contrast, countries that avoided a banking crisis recorded a much milder average impact of $20 \%$ depreciation against the time of peg failure, with the nadir of the exchange rate depreciation for these non-banking-crisis countries happening around 15 months following peg failure. This indicates that although the loss in value of the currency was more severe for banking crisis countries, the currency started regaining in value sooner compared to countries that did not see a banking crisis.

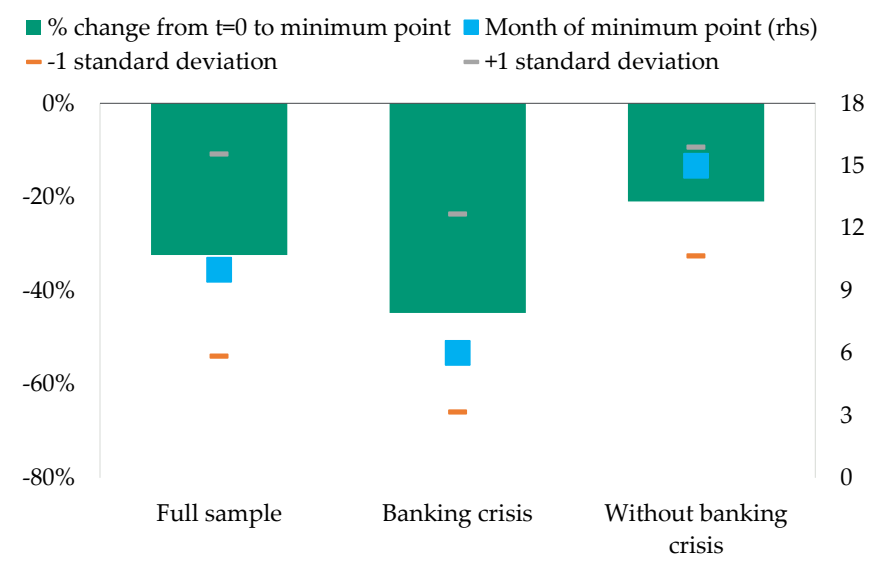

Figure 3. Exchange rate depreciation following currency peg abandonment. This figure demonstrates the largest degree of exchange rate depreciation and month of minimum point after peg failure. Green bars refer to the greatest average percent depreciation in the exchange rate against the anchoring peg currency, and the blue square markers refer to the month in which this depreciation occurred following peg abandonment. Standard deviation markers refer to the sample standard deviation around the minimum point.

On a country by country basis, Figure 4 shows the instances in which the exchange rate depreciation exceeded 50\% from the time of peg failure, including Indonesia, Turkey and Argentina, within a few months of abandoning their pegs. Such magnitude of depreciation will have severe consequences for both growth and financial stability. 
However, there are other examples where the authorities have moved to floated currencies more gradually, which can result in less violent moves in the exchange rate from the point of flotation. For instance, when Egypt floated its exchange rate in 2016, it saw a 14\% depreciation in the second month after flotation, but the exchange rate then stabilised at around $10 \%$ below the previously pegged value (see Figure 4). Nonetheless, it is important to note that the authorities had already devalued its pegged currency by $13 \%$ some ten months before it moved to a floating currency. Additionally, that flotation only occurred after political and social stability had already improved and coincided with a series of measures aimed at restoring macroeconomic stability, supported by strong financial flows from donors. There have been other instances of shifts in pegs prior to their abandonment: for example, Azerbaijan also moved its peg lower in February 2015-devaluing by 25\%-before the currency was ultimately floated in December of that year.

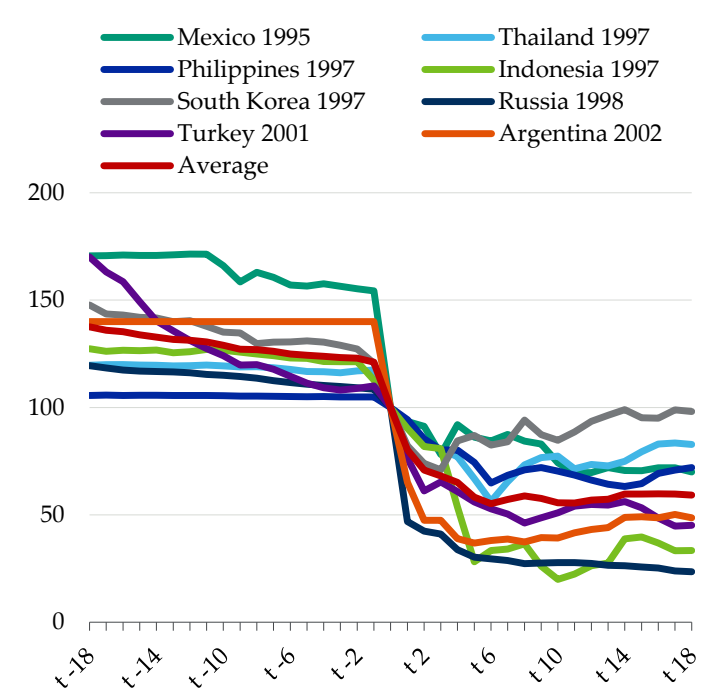

(a)

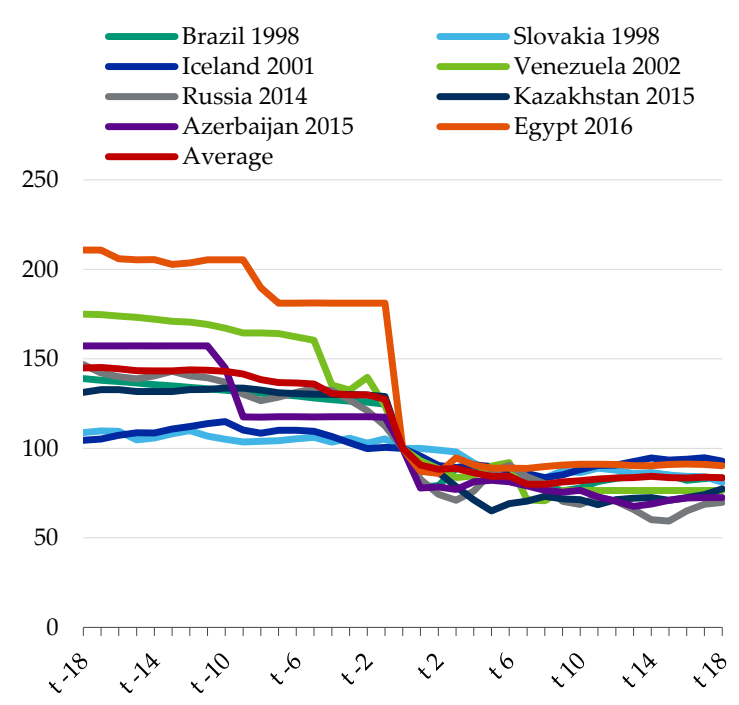

(b)

Figure 4. Change in exchange rates around time of peg abandonment. This figure demonstrates the impact on exchange rates around the time of peg failure: (a) shows banking crisis countries; (b) shows countries without banking crisis. The vertical axis showing the exchange rates against the anchor currency in index terms where the month of peg failure $=100$. The horizontal axis reflects the 18 months, on either side, of the point of peg failure.

The impact of a peg failure on economic growth prospects can be very damaging as a result of significantly increased uncertainty, instability and contagion of risk across sectors. As monetary policy is largely unable to respond to domestic developments while the peg remains, support for the economy is typically limited to fiscal policy and is often insufficient.

Average real GDP growth in the year after the peg failed was around $-3 \%$ for countries that did not see a banking crisis, compared with a figure of around $-6.5 \%$ for countries that also suffered a banking crisis (see Figure 5). Apart from this initial growth impact, the cumulative damage from exchange rate pegs failing is also substantial. It is hard to gauge this accurately, given that many countries enjoyed strong growth before their pegs broke: our simple assumption is that, if the peg had not failed, growth over the following 18 months would have continued at its average rate over the five years before the peg failure. ${ }^{6}$ On this basis, the cumulative GDP shortfall in countries without banking crises was 3.5\% on average; but in countries with banking crises it was larger at $6 \%$ after 18 months. Both of these figures include some partial recovery over the 18-month period, with a peak

6 This is a critical assumption, notably as some countries may have seen substantial capital inflows and unsustainable growth before the peg failed. 
GDP shortfall of $4.5 \%$ after nine months where there was no banking crisis, and a shortfall of $7.6 \%$ after 12 months for countries with banking crises.

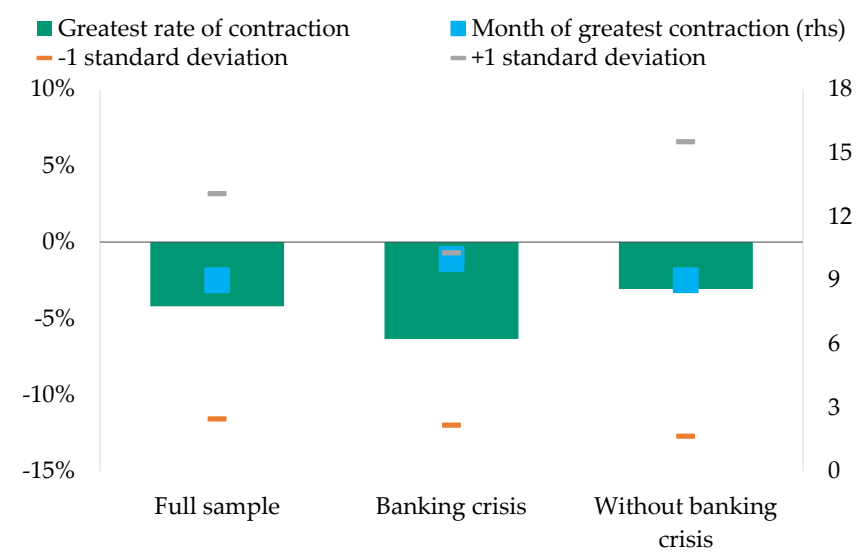

Figure 5. Contraction in annual real GDP growth following currency peg abandonment. This figure demonstrates the largest degree of economic shrinkage in real terms and month in which this shrinkage occurred after peg failure. Green bars refer to the greatest average percent contraction in real GDP, and the blue square markers refer to the month in which this shrinkage occurred following peg abandonment. Standard deviation markers refer to the sample standard deviation around the greatest contraction point.

The fact that the GDP shortfall is higher when both banking and currency crises occur, rather than instances of the exchange rate peg failing (but no banking crisis) is consistent with previous research noted earlier, although the magnitudes are somewhat smaller. While this may suggest that the impact of crises has changed over time, it could also reflect policymakers taking different stances given they have more (global) experience in what happens when risks crystallize. In light of past research, it is also unsurprising that the coincidence of currency and banking crises results in greater output losses. In particular, where economies are already struggling with the higher inflation and negative real wage effects engendered by the currency depreciation, having a banking sector that is experiencing its own crisis-leading to a credit crunch-will also imply a fall in output, and indeed likely result in further negative wealth shocks on corporates and households, as bad debts are ultimately re-structured, and may even spillover to the sovereign balance sheet if public recapitalization is required. Furthermore, if the banking sector is the main source of finance to the real economy (with capital markets being relatively underdeveloped in the countries in our sample), its crisis will also impede the process of (re)allocating funds to new investments and businesses that can facilitate the broader transformation and hence recovery of the economy.

Figure 6 illustrates the impact of peg failure on real GDP growth per country. It is clear that if risks spread to the banking system the reduction in economic activity is substantial, with contraction on an annual basis often exceeding $5 \%$ for several months following currency flotation. Although Venezuela circumvented a systemic banking crisis, the recession in 2002 was significant. A fall in oil prices acted as a trigger, but the recession was also fueled by political instability-including a failed coup d'etat and the imprisonment of then-president Hugo Chávez-as well as business strikes and the withdrawal of foreign investment. The peg was abandoned in June 2002. However, following another speculative attack and business strikes in December 2002, Venezuela reinstated a peg in February 2003, alongside extensive capital controls. 


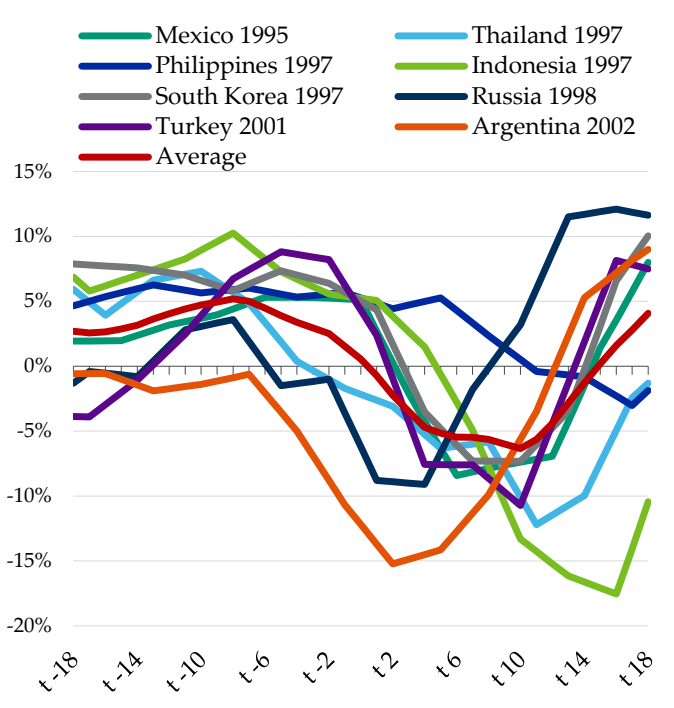

(a)

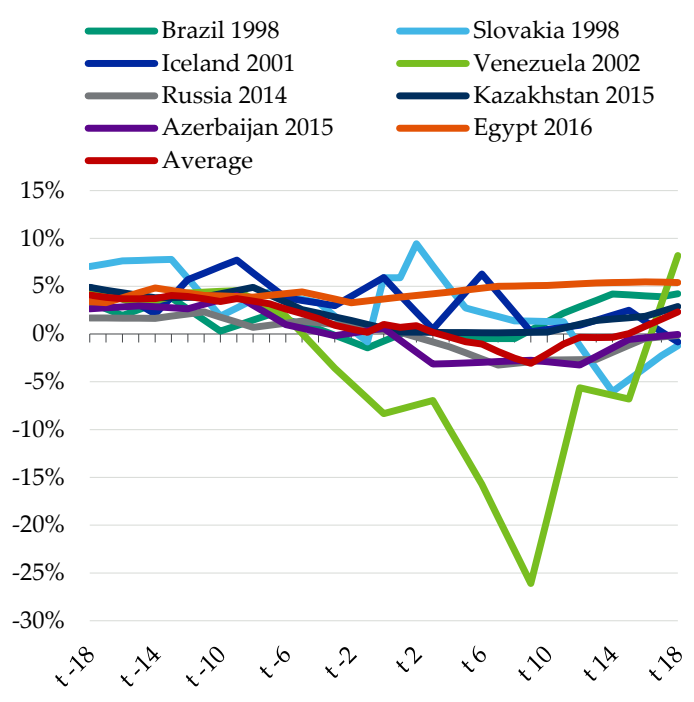

(b)

Figure 6. Impact on real GDP growth around time of peg abandonment. This figure demonstrates the impact on real GDP growth around the time of peg failure: (a) shows banking crisis countries; (b) shows countries without banking crisis. The vertical axis showing the annual growth rates in percentage terms. The horizontal axis reflects the 18 months, on either side, of the point of peg failure.

When the currency starts falling in value, its purchasing power declines, which fuels domestic inflationary pressures. There is a significant difference in the magnitude of impact between banking crisis countries and non-crisis countries in terms of the impact on inflation rates (see Figure 7). The substantial currency depreciation experienced by these countries contributed to inflationary pressures as imports became relatively more expensive. At the peak of impact, annual inflation of crisis countries had on average risen by 35 percentage points from a rate of $11 \%$ at the time the peg broke to $46 \%$ at its peak a year later. Countries that avoided a banking crisis saw an average increase of 10 percentage points from $9 \%$ to $19 \%$.

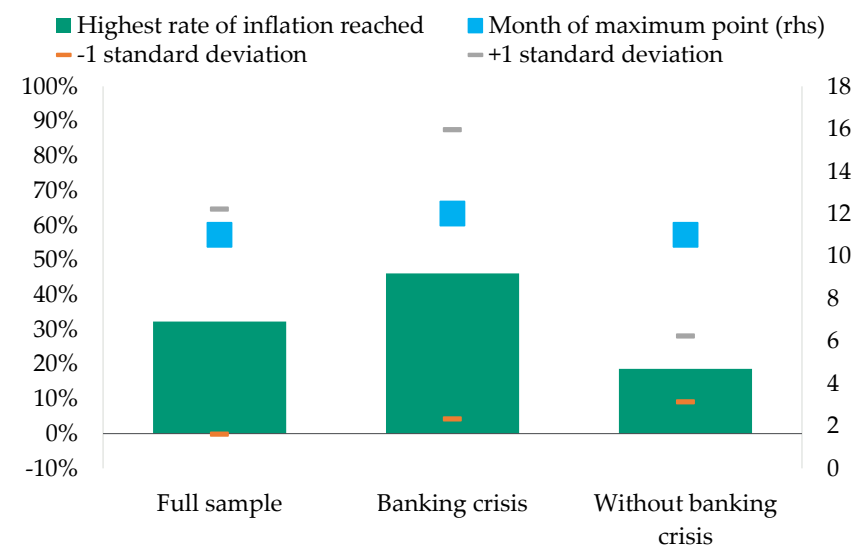

Figure 7. Annual rate of consumer price index (CPI) inflation following peg abandonment. This figure demonstrates the highest CPI inflation rate reached and the month in which this rate occurred after peg failure. Green bars refer to the greatest average rate of annual inflation, and the blue square markers refer to the month in which this inflation peak occurred following peg abandonment. Standard deviation markers refer to the sample standard deviation around the maximum point.

Nevertheless, among the countries that have suffered a systemic banking crisis, the experiences vary widely. Southeast Asian countries saw marginal increases in inflation from the rates prevalent 
before the currency was floated, while Russia, Indonesia, and Turkey have recorded inflation well over $70 \%$ (see Figure 8).

Venezuela and Egypt are the outliers in the set of countries that did not endure a banking crisis. The rise in Egypt's inflation rate was partly driven by the removal of subsidies around the time of the peg dissolution, rather than just the peg abandonment itself. During its crisis, Egypt also received support from its Gulf state neighbours as well as an extended fund facility arrangement of $\$ 12$ billion from the IMF, which further helped to mitigate the overall economic impact.

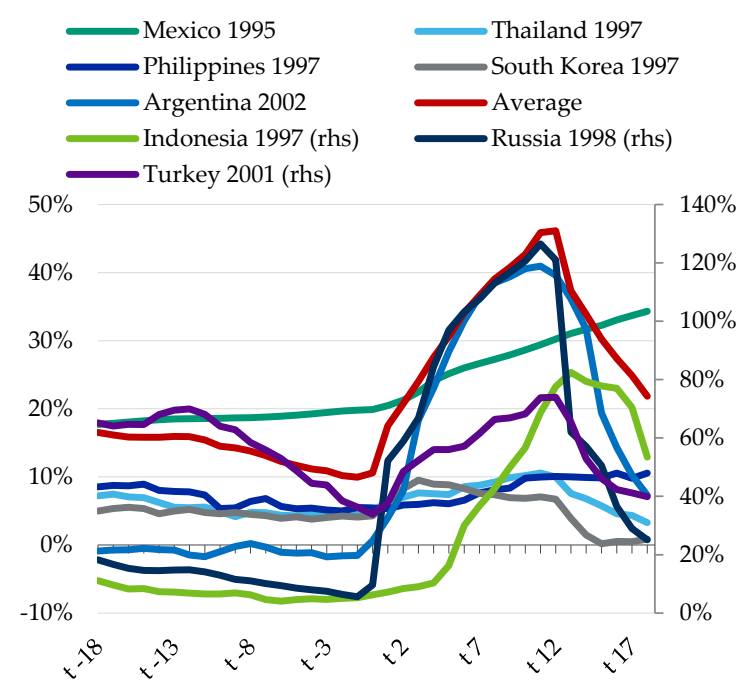

(a)

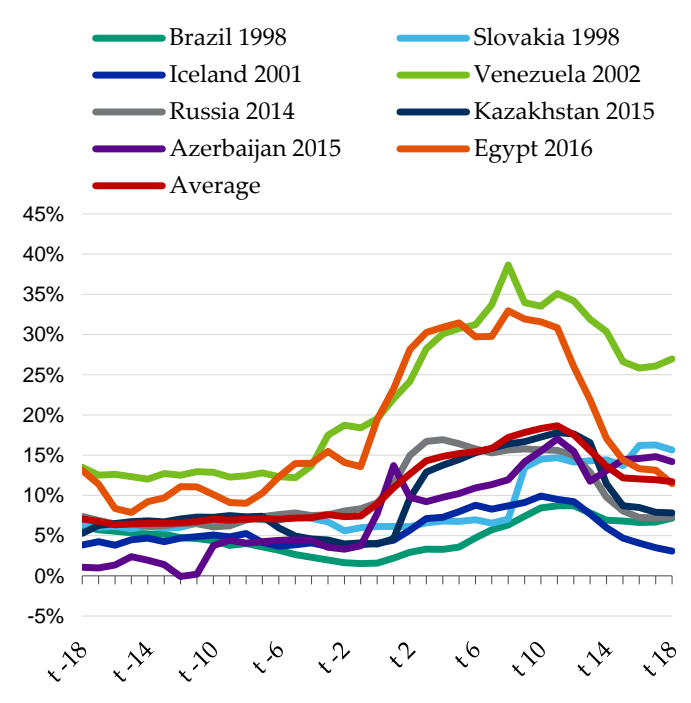

(b)

Figure 8. Impact on annual rate of CPI inflation around time of peg abandonment. This figure demonstrates the impact on CPI inflation around the time of peg failure: (a) shows banking crisis countries; (b) shows countries without banking crisis. The vertical axis shows the annual rates in percentage terms. The horizontal axis reflects the 18 months, on either side, of the point of peg failure.

As uncertainty grows, economic activity slows, inflationary pressures build, and employers pull back on hiring intentions and reduce staff numbers. As a result, unemployment tends to rise following peg failure. Figure 9 shows that countries that avoided a banking crisis reached a higher peak rate of unemployment from the time of peg failure compared with those that went through one, but in part this reflected the higher starting point. The rise in unemployment was greater for banking crisis countries, on average hovering around $7-8 \%$ in the months before the peg broke and subsequently rising by 2.2 percentage points to about $10 \%$. On the other hand, countries that avoided such a crisis on average had an unemployment rate of around $12.5 \%$ at the time of peg failure, with the rate rising to almost $14 \%$ about a year later. 


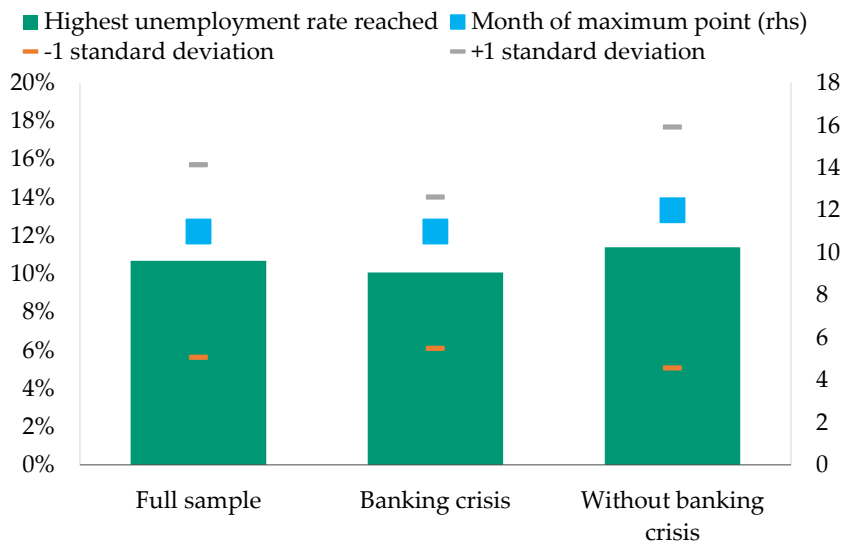

Figure 9. Unemployment rate following currency peg abandonment. This figure demonstrates the highest level of unemployment reached and the month in which this rate occurred after peg failure. Green bars refer to the greatest average level of unemployment, and the blue square markers refer to the month in which this unemployment peak occurred following peg abandonment. Standard deviation markers refer to the sample standard deviation around the maximum point.

Among countries that circumvented a banking crisis, Venezuela and Slovakia recorded the largest increases in unemployment of around 4 percentage points after abandoning their pegs (see Figure 10). In addition to recording the most pronounced rise in unemployment, these countries also started from the highest levels at the time the peg broke, of around a 15\% unemployment rate. At the other end of the spectrum, Egypt had declining unemployment rates following the exchange rate regime shift.

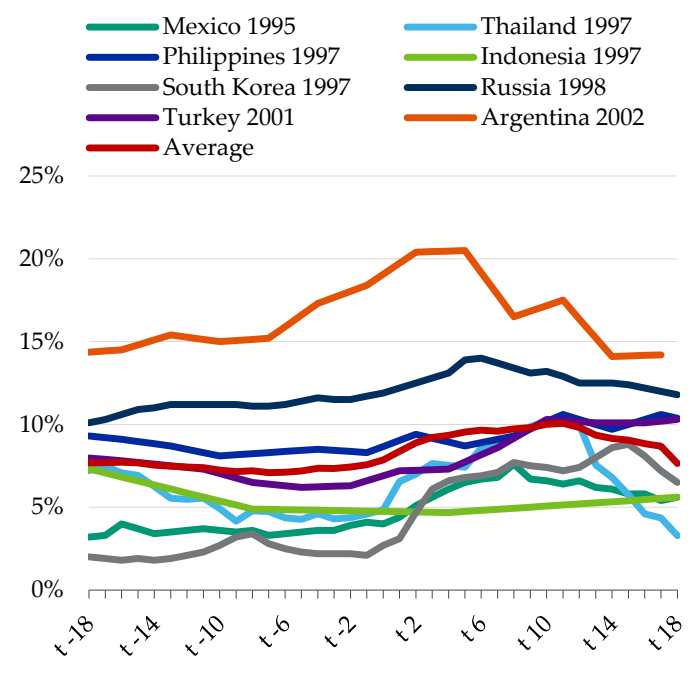

(a)

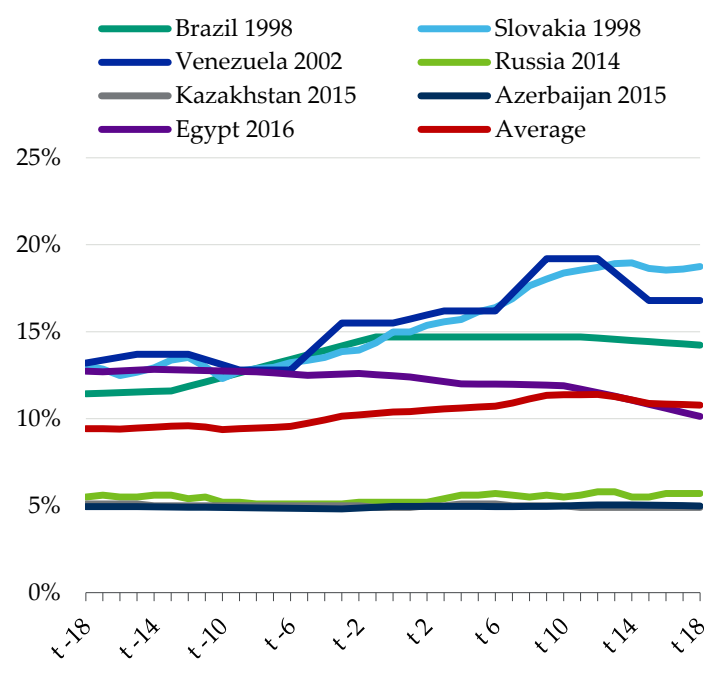

(b)

Figure 10. Impact on unemployment around time of peg abandonment. This figure demonstrates the impact on unemployment around the time of peg failure: (a) shows banking crisis countries; (b) shows countries without banking crisis. The vertical axis shows the annual rates in percentage terms. The horizontal axis reflects the 18 months, on either side, of the point of peg failure.

Overall this analysis demonstrates that, while countries' individual experiences differ, the abandonment of an exchange rate peg in order to move to a floating currency regime is typically associated with a dramatic weakening of macrofinancial conditions. This, in turn, will engender widespread economic and financial damage within the economy. If the peg break also coincides with a banking crisis, the negative credit impact could be much more substantial than would otherwise be the case, as noted in previous research. Nevertheless, regardless of whether there was a banking crisis, countries start to show signs of recovery after the same amount of time once the currency floated. 


\section{Conclusions}

The choice and structure of a country's exchange rate regime has wide implications for the effectiveness and flexibility of policy tools, as well as for economic and financial stability. One choice is to peg the domestic currency to a foreign one, but if that peg proves unsustainable, the macroeconomic and financial damage when the peg breaks can be substantial. In this paper, we examine 21 instances where exchange rate pegs have been abandoned in the past, to gauge the potential economic and financial turmoil associated with pegs failing. The data sample covers a selected number of major exchange rate shifts over the past thirty years, spanning from the Latin America currency crises during the 1990s to the recent peg abandonment in Egypt at the end of 2016. Whether the shift from a managed exchange rate regime to floating occurs in conjunction with wider systemic economic and financial stress, or whether it takes place in a more contained fashion, has implications for the magnitude and persistence of the economic and financial turmoil at the time the peg is abandoned. Given the close interconnection of banks to the sovereign and real economies, the build-up of risks often flows through to, and can also be magnified by, the banking system. We therefore examine the interaction of currency peg abandonment with the simultaneous occurrence of a banking crisis to investigate the different circumstances and impacts of exchange rate pegs failing. We find that countries that simultaneously suffered a systemic banking crisis during the period of exchange rate regime shift also experienced significantly greater economic and financial damage following the adoption of a freely floating exchange rate. Nevertheless, regardless of whether there was a banking crisis, countries start showing signs of recovery after the same amount of time once the currency floated.

Author Contributions: Conceptualization, C.E.; Data curation, E.G.; Formal analysis, E.G.; Investigation, E.G.; Methodology, C.E. and E.G.; Writing—original draft, E.G.; Writing—review \& editing, C.E.

Funding: This research received no external funding.

Acknowledgments: The authors are grateful for helpful comments from former and present colleagues at the Bank of England, Moody's Investor Service, and elsewhere. All errors remain our own.

Conflicts of Interest: The authors declare no conflict of interest.

\section{Appendix A}

Table A1. Sample of countries that abandoned their currency pegs, first half of sample.

\begin{tabular}{|c|c|c|c|c|c|}
\hline Country & $\begin{array}{l}\text { Date of Peg } \\
\text { Failure }\end{array}$ & $\begin{array}{l}\text { Starting Currency } \\
\text { Regime }\end{array}$ & $\begin{array}{c}\text { New Currency } \\
\text { Regime }\end{array}$ & $\begin{array}{c}\text { Start of } \\
\text { Systemic } \\
\text { Banking Crisis }\end{array}$ & $\begin{array}{l}\text { Date of } \\
\text { Sovereign } \\
\text { Default }\end{array}$ \\
\hline Thailand & Jul 1997 & $\begin{array}{l}\text { Fixed peg against a basket } \\
\text { of currencies, } \\
\text { especially USD }\end{array}$ & $\begin{array}{l}\text { Floating, but with } \\
\text { market interventions }\end{array}$ & Oct 1997 & - \\
\hline Philippines & Jul 1997 & $\begin{array}{l}\text { Officially floating, but } \\
\text { with admitted market } \\
\text { interventions }\end{array}$ & $\begin{array}{l}\text { Floating, but with } \\
\text { market interventions }\end{array}$ & Mar 1998 & - \\
\hline Czech Republic & May 1997 & $\begin{array}{l}\text { Fixed peg versus USD, but } \\
\text { towards the end of the } \\
\text { regime the currency was } \\
\text { managed within } \\
\text { widening bands }\end{array}$ & $\begin{array}{l}\text { Managed float, but no } \\
\text { stated bands; Currency } \\
\text { appreciated after } \\
\text { regime shift }\end{array}$ & Jun 1996 & - \\
\hline Indonesia & Aug 1997 & $\begin{array}{l}\text { Fixed peg against a basket } \\
\text { of currencies, but towards } \\
\text { the end of the regime the } \\
\text { currency was managed } \\
\text { within widening bands }\end{array}$ & $\begin{array}{l}\text { Floating, but with } \\
\text { market interventions }\end{array}$ & Dec 1997 & - \\
\hline
\end{tabular}


Table A1. Cont.

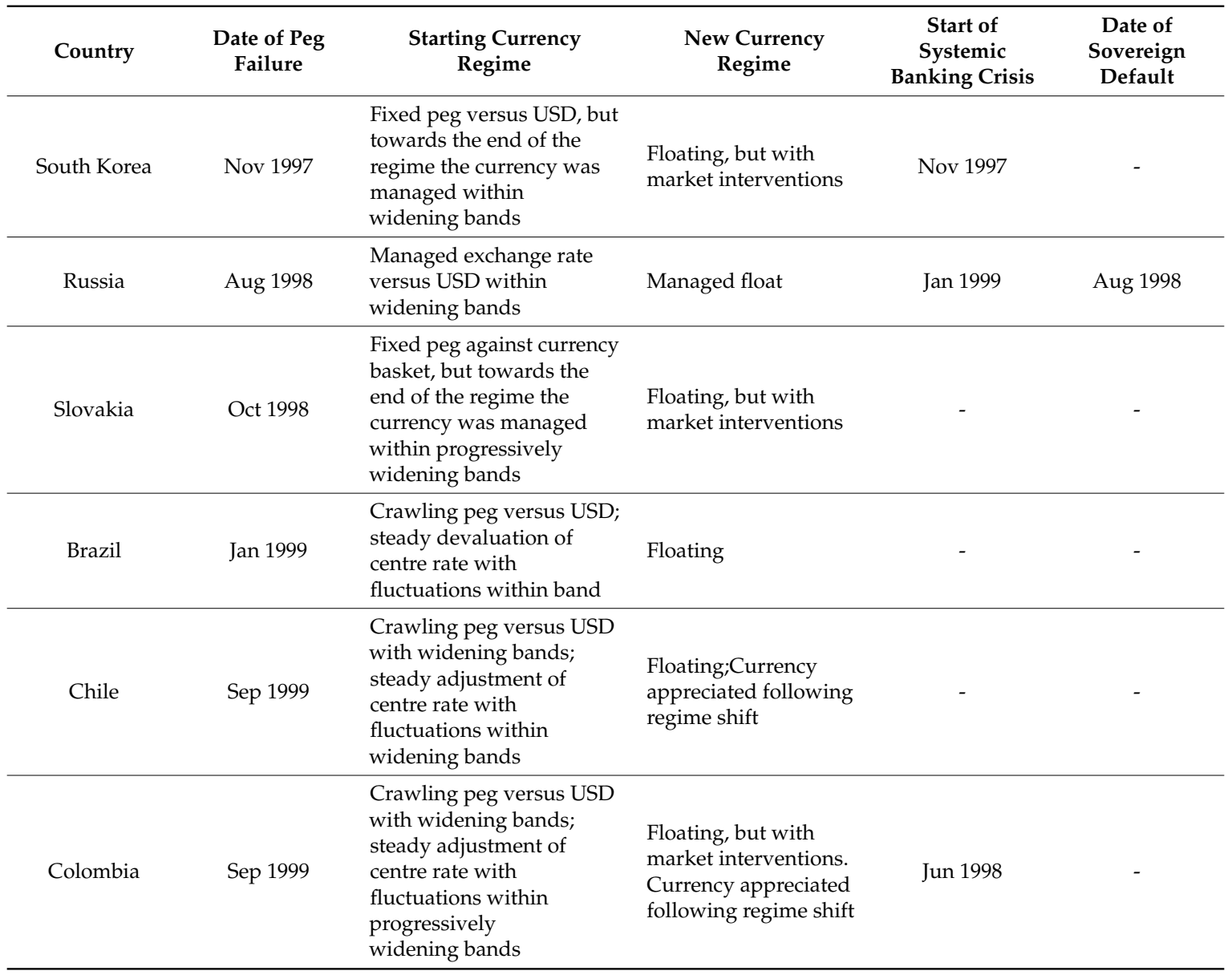

Table A2. Sample of countries that abandoned their currency pegs, second half of sample.

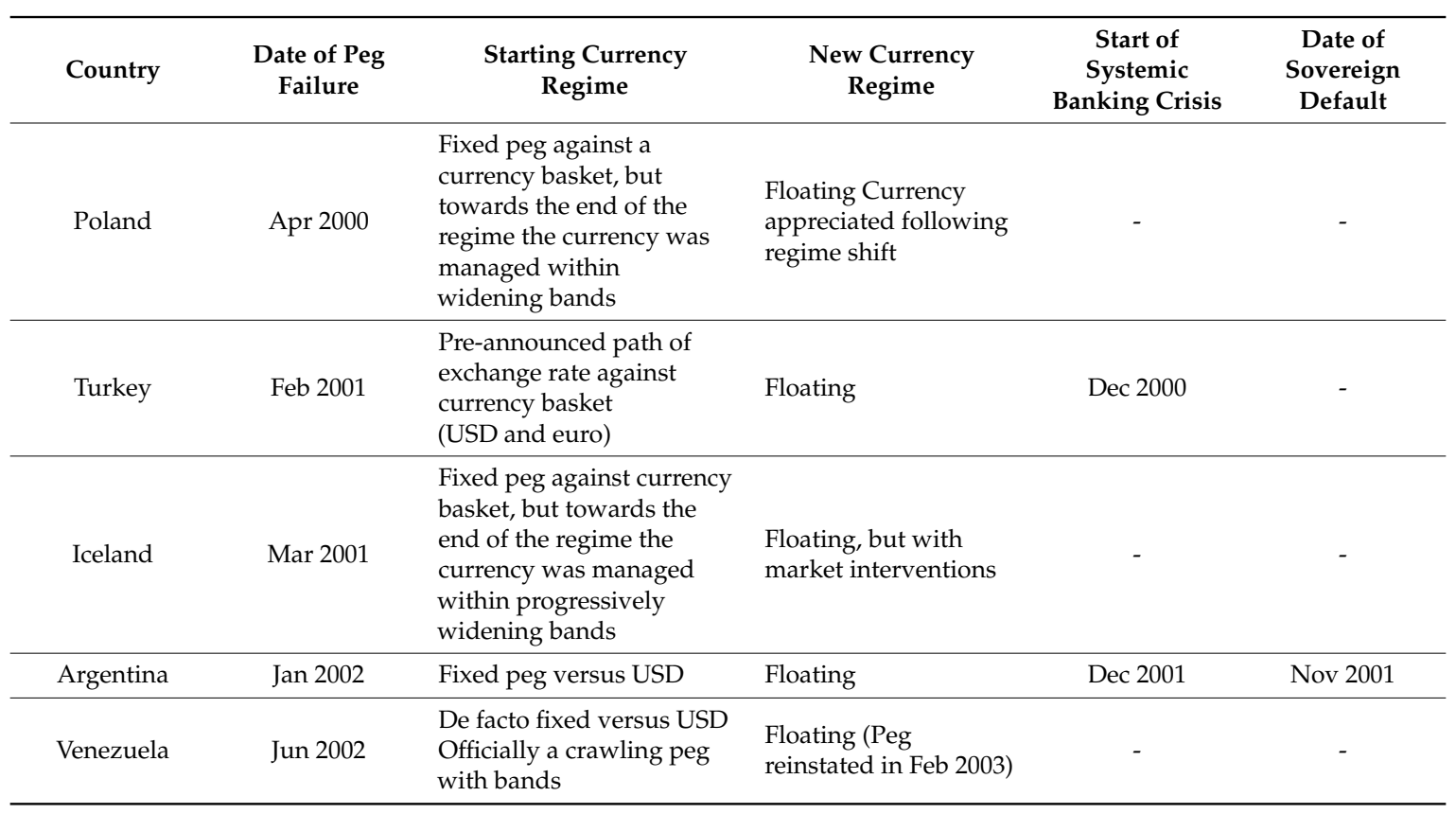


Table A2. Cont.

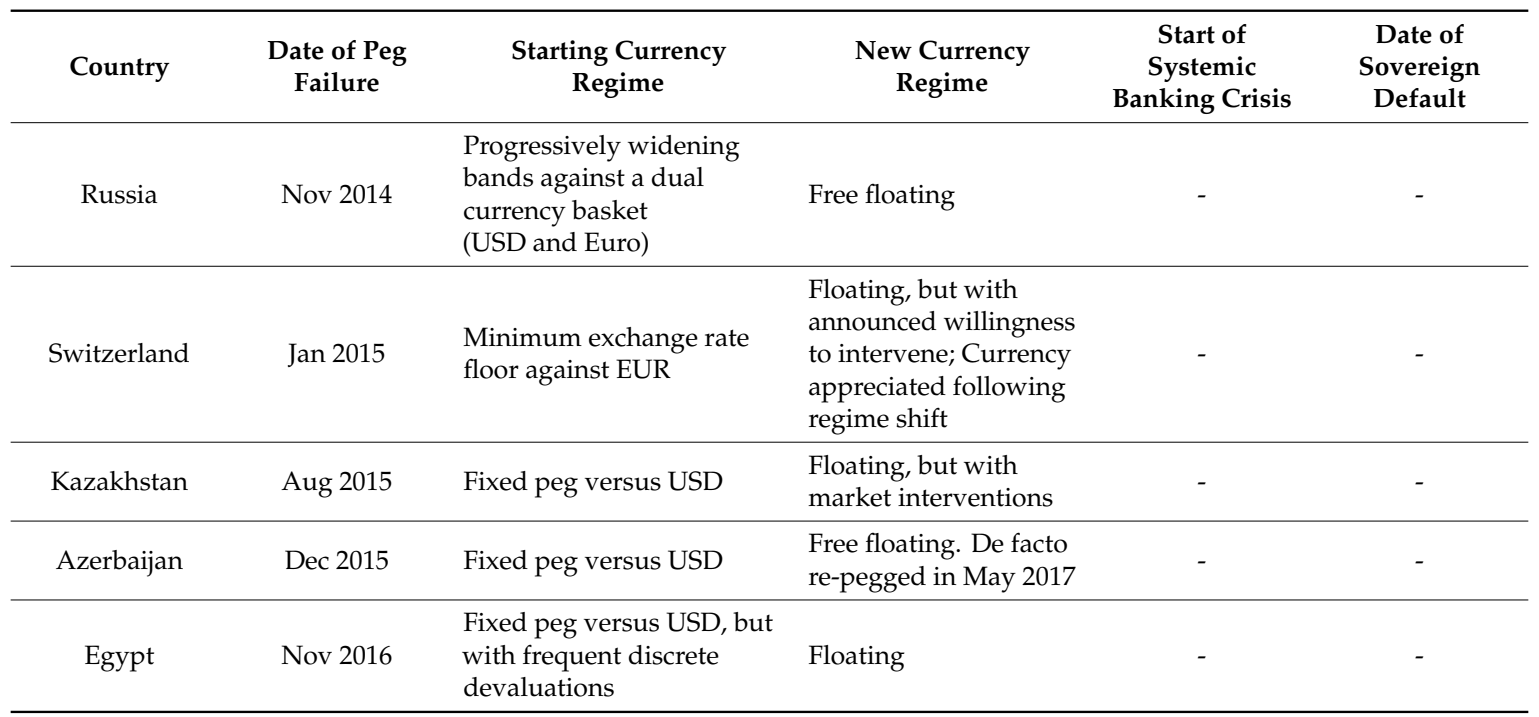

\section{References}

Aghion, Philippe, Philippe Bacchetta, and Abhijit Banerjee. 2001. Currency Crises and Monetary Policy in an Economy with Credit Constraints. European Economic Review 45: 1121-50. [CrossRef]

Arteta, Carlos, and Barry Eichengreen. 2002. Banking Crises in Emerging Markets: Presumptions and Evidence. In Exchange Rate and Financial Vulnerability in Emerging Markets. Edited by Mario Blejer and Marko Skreb. Cambridge: MIT Press.

Cavallo, Michele, Kate Kisselev, Fabrizio Perri, and Nouriel Roubini. 2005. Exchange Rate Overshooting and the Costs of Floating. Working Paper No. 2005-07, Federal Reserve Bank of San Francisco, San Francisco, CA, USA.

Chang, Roberto, and Andres Velasco. 2000. Financial Fragility and the Exchange Rate Regime. Journal of Economic Theory 92: 1-34. [CrossRef]

Corsetti, Giancarlo, Paolo Pesenti, and Nouriel Roubini. 1998. What Caused the Asian Currency and Financial Crisis? Part I: A Macroeconomic Overview. NBER Working Paper No. 6833, National Bureau of Economic Research, Cambridge, MA, USA.

Dekle, Robert, and Kenneth Kletzer. 2001. Domestic Bank Regulation and Financial Crises-Theory and Empirical Evidence from East Asia. In Preventing Currency Crises in Emerging Markets. Edited by Sebastian Edwards and Jeffrey A. Frankel. Chicago: University of Chicago Press.

Ellis, Colin, and Georgina Smartt. 2018. Currency Composition of Foreign Reserves Continues to Change only Gradually, with Any Major Shifts Likely Years Away. London: Moody's Investors Service.

Ellis, Colin, Marie Diron, and Elena Duggar. 2015. Credit Implications of Exchange-Rate Movements Depend on Source of the Shock and Issuers' Exposures. London: Moody's Investors Service.

Fleming, Marcus. 1962. Domestic financial policies under fixed and under floating exchange rates. International Monetary Fund (Staff Papers) 9: 369-80. [CrossRef]

Gupta, Poonam, Deepak Mishra, and Ratna Sahay. 2003. Output Response during Currency Crises. Working Paper No. 03/230, International Monetary Fund, Washington, DC, USA.

Hutchinson, Michael, and Ilan Noy. 2005. How bad are twins? Output costs of currency and banking crises. Journal of Money, Credit and Banking 37: 725-52. [CrossRef]

Kaminsky, Graciela, and Carmen Reinhart. 1999. The Twin Crises: The Causes of Banking and Balance-of-Payments Problems. American Economic Review 89: 473-500. [CrossRef]

Laeven, Luc, and Fabian Valencia. 2018. Systemic Banking Crises Revisited. IMF Working Paper 18/206, International Monetary Fund, Washington, DC, USA.

Mundell, Robert. 1960. The monetary dynamics of international adjustment under fixed and flexible exchange rates. The Quarterly Journal of Economics 74: 227-57. [CrossRef] 
Mundell, Robert. 1963. Capital mobility and stabilization policy under fixed and flexible exchange rates. Canadian Journal of Economics and Political Science 29: 475-85. [CrossRef]

Rey, Helen. 2015. Dilemma Not Trilemma: The Global Financial Cycle and Monetary Independence. NBER Working Paper No. 21162, National Bureau of Economic Research, Cambridge, MA, USA.

(C) 2019 by the authors. Licensee MDPI, Basel, Switzerland. This article is an open access article distributed under the terms and conditions of the Creative Commons Attribution (CC BY) license (http://creativecommons.org/licenses/by/4.0/). 